\title{
Opinnäytetyön ohjaaminen ja opiskelijan motivaatio
}

- esimerkkinä sosiaalialan aikuisopiskelijan

\section{opinnäytetyö}

\author{
MIKA ALAVAIKKO
}

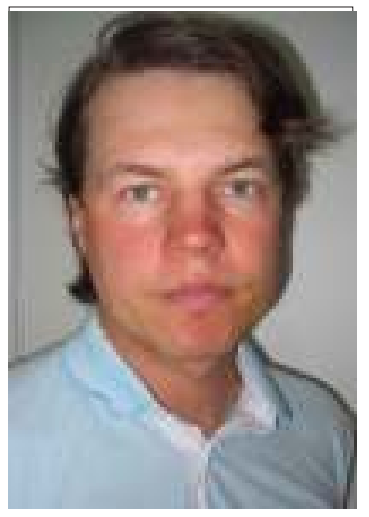

"Oli ohjaus ohjaajan ja opinnäytetyön tekijän välistä yksilöohjausta tai ryhmässä tapahtuvaa, on sen tärkein anti ohjausprosessissa syntyvä tietoisuus siitä, että joku muu - ohjaaja, vertaisryhmä seuraa ja on tietoinen kokijan omasta prosessista. Tämän tietoisuuden merkitys on huomattavasti suurempi kuin minkään tiedollisen ohjauksen merkitys", kirjoittaa Mika Alavaikko artikkelissaan. Hän tarkastelee erityisesti opiskelijan motivaatiota. pinnäytetyön ohjaamista on mahdollista jäsentää eri tavoin. Sitä voidaan pohtia hyvän ohjaajan määreiden kautta (Easterby-Smith et al. 2002,15) tai ohjaajan käyttäytymisen ja oikean ohjaajan valinnan kysymysten kautta (Zhao et al. 2007). Ohjaamista työnä ja ohjausuhdetta yleensä voidaan tarkastella myös erilaisten metaforien ja mallien avulla (Mackinnon 2004).

Opinnäytteiden ohjaamista käsittelevää tutkimusta leimaa asetelman refleksiivisyys ja roolien päällekkäisyys. Opinnäytetyön ohjaaja on itsekin ollut joskus ohjattava. Toisaalta kirjoittaja voi paitsi kirjoittaa ohjaamisesta, itsekin toimia opinnäytetyön ohjaajana.

Tässä artikkelissa tarkastelen opinnäytetyön prosessia opiskelijan motivaation käsitteellistämisen näkökulmasta. Opiskelijan motivaatio ymmärretään helposti valmiina, olemassa olevana suureena. Opiskelijalla katsotaan joko olevan motivaatiota tai sitä ei ole. Näin yksinkertaista ohjaaminen ei kuitenkaan ole. Oletan motivaation vaihtelevaksi tekijäksi, johon ohjaajan toiminta vaikuttaa.

Juha Hakala nosti artikkelissaan "Tutkielmaopintojen ohjaaja tarvitsee muutakin kuin tukevan oppituolin" (1995) opiskelijan motivaation tarkastelun kohteeksi. Käsitteellistän seuraavassa opiskelijan motivaatiota ja pyrin kuvaamaan ohjauksen organisatoristen puitteiden, ohjaajan käyttäytymisen ja opiskelijan motivaation välistä suhdetta.

Opiskelijan motivaatiota tarkastelen Anne Birgit Yeunin (2004) motivaatiokartan avulla. Tutkiessaan vapaaehtoistyöntekijöiden motivaatiota Yeung muodosti moniuloitteisen kartan, jossa motivaatio osallistua vapaaehtoistyöhön jaetaan moneen eri ulottuvuuteen. (Yeung 2004, 32.)

Yeungin kuvion (ks. seuraava sivu) vasemmalla puolella ovat persoonan sisäänpäin suuntautuneet motivaation osa-alueet: saaminen, jatkuvuus, etäisyys ja ajattelu. Kutakin näistä vastaa persoonasta ulospäin suuntautunut motivaation sosiaalinen ulottuvuus: antaminen, uuden löytäminen, läheisyys ja toiminta. Kuviota ei pidä lukea persoonallisuuden typologiana. Se on pikemminkin Yeungin aineistostaan tulkitsema kuvaus ilmiöstä nimeltä "vapaaehtoistyöntekijän motivaatio". (emt. 33.)

Käytän Yeungin motivaatiokarttaa paitsi aineis- 


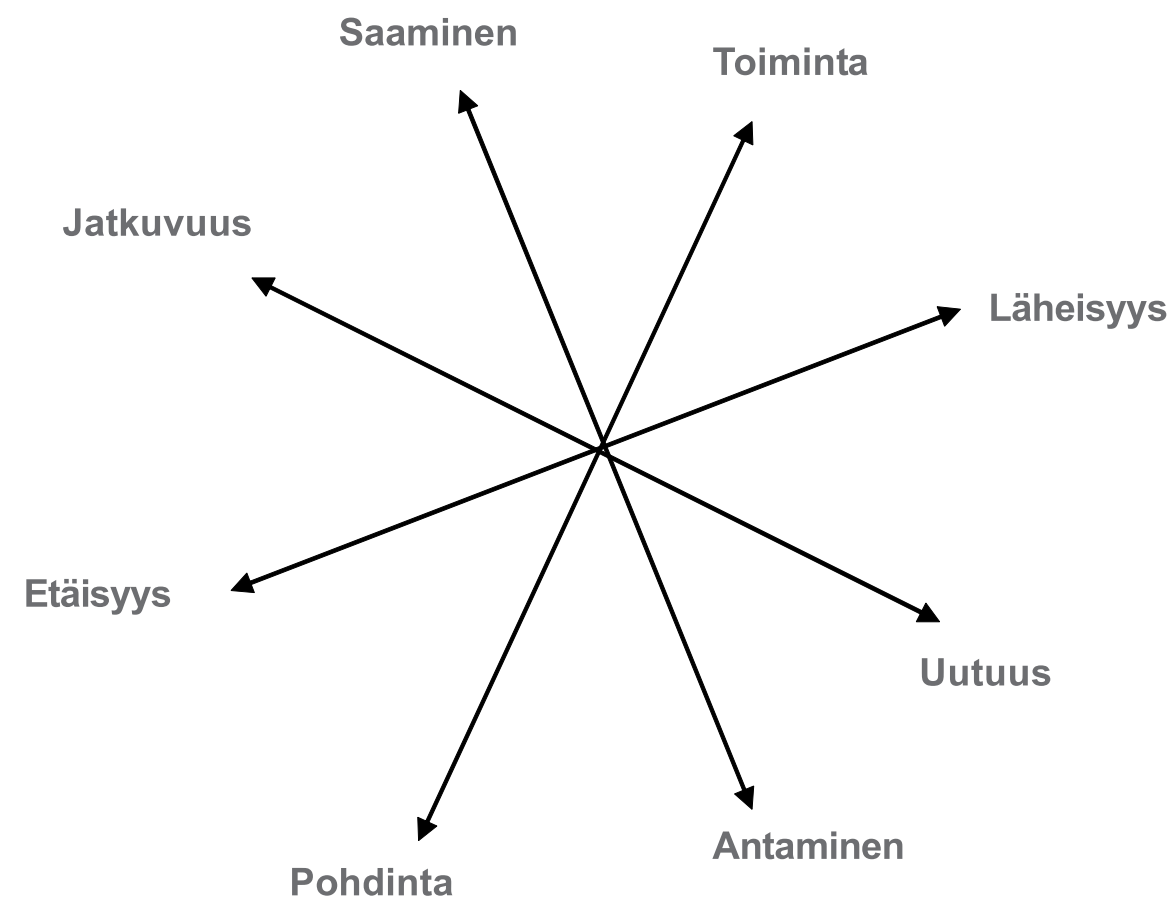

tonkeruuni lähtökohtana, myös ajattelua jäsentävänä mallina. Opinnäytetyön tekeminen ei ole vapaaehtoistyötä. Kuitenkin siinä on tulkintani mukaan pitkälti kysymys motivaatiosta. Yeungin motivaatiokartta tarjoaa hyvän lähtökohdan tarkastella opinnäytetyöntekijän motivaation eri ulottuvuuksia.

\section{Tieto - motivaatio - kokemus}

Ennen aineistonkeruun jäsentelyä muutama sana taustalla olevasta ammatillisesta ajattelustani. Opinnäytetyön tekemistä voidaan jäsentää kolmen käsitteen avulla. Nämä käsitteet ovat tieto, kokemus ja motivaatio. Opiskelijan motivaatio, johon tässä artikkelissa keskityn, on vain yksi opinnäytetyön tekemisen peruskäsite.

Hakkarainen, Lonka ja Lopponen (2004) jakavat oppimisen järkeen, kulttuuriin ja tunteisiin. Omassa mallissani noita käsitteitä vastaavat tieto, kokemus ja motivaatio. Tieto on sitä, mitä opettaja ja oppilaitos kykenevät opiskelijalle välittämään. Opinnäytetyön prosessiin liittyen tieto on tietoa tutkimusmenetelmistä, niiden soveltamisesta sekä niitä esittelevistä kirjoista ja artikkeleista. Tietoa on myös kyky avata tutkimusmenetelmiin liittyvää käsitteistöä opiskelijoille.

Mitä tarkoitetaan tutkimusmenetelmällä? Mitä on laadullinen tutkimus? Kuinka tutkimusprosessi etenee? Millaisia laadullisen aineiston analyysitapoja on olemassa? Mikä on laadullisen ja määrällisen tutkimuksen ero? Näihin kaikkiin kysymyksiin on mahdollista vastata tiedolla. Tieto voi olla kokemusperäistä, kirjallisuudesta peräisin tai niiden yhdistelmä.

Kokemus opinnäytetyöprosessissa viittaa opiskelijan kokemukseen prosessista. Hakkarainen, Lonka ja Lopponen (2004) puhuvat kulttuurista, joka voidaan käsittää esimerkiksi oppilaitoksessa vallitseviksi arvoiksi ja käytännöiksi. Jokainen oppilaitos järjestää opinnäytetyöhön liittyvän opetuksen hiukan eri tavalla. Opinnäytetyö myös saa aina hiukan erilaisen paikan tai arvon eri oppilaitoksissa. Voidaan puhua yleisesti oppilaitoskulttuurista ja erikseen opinnäytetöihin liittyvästä oppilaitoskulttuurista. Opiskelija on tämän kulttuurin kokija: hän kohtaa ja käy läpi oppilaitoksen ohjeet, käytännöt ja arvot liittyen opiskeluun yleensä ja opinnäytetyöhön erityisesti.

Tähän artikkeliin kerättiin aineisto Diakoniaammattikorkeakoulun Järvenpään toimipaikan sosionomi- ja sosiaalialan jatkotutkinnon opiskelijoilta. Opiskelijoiden opinnäytetyöhön liittyvä ohjaus ja opetus oli järjestetty siten, että opiskelija työsti opinnäytetyötään seminaarissa. Sosionomi opiskelija osallistuu seminaariin lähtökoh- 
taisesti kolmen lukukauden ajan. Pakollisia osallistumiskertoja menetelmäopetuksen ja muun aihepiiriin liittyvän opetuksen kanssa kertyy noin kaksikymmentä. Varsinaisiin seminaaritapaamisiin opiskelija osallistuu vähintään kymmenen kertaa. Seminaarin jäsenmäärä vaihtelee kymmenestä useaan kymmeneen.

Seminaaritapaamisessa käsitellään kerrallaan yhdestä kolmeen opiskelijan tuottamaa paperia. Nämä paperit ovat joko niin sanottuja ideapapereita (opinnäytetyön ensimmäinen hahmotus), tutkimussuunnitelmia tai opinnäytetyön osia. Opinnäytetyön osan muodostaa yksi mahdollisimman valmis luku sekä jäsennys muusta opinnäytetyön sisällöstä. Tutkimussuunnitelma ja opinnäytetyön osa käsitellään aina saman kaavan mukaan: opiskelija esittelee tuotoksensa, ennalta sovittu opponentti antaa suullisen ja kirjallisen opponoinnin, käydään yleiskeskustelu ja lopuksi ohjaaja kommentoi paperia. Vertaispalaute on siis tärkeä. Prosessin loppuvaiheessa valmis työ käsitellään vielä loppuseminaarissa.

Kolmas keskeinen käsite on opiskelijan motivaatio. Suoraviivaisin ja ehkä kaikkein yleisin tapa hahmottaa motivaatio on ajatella, että joko sitä on tai sitten sitä ei ole. Tällä tavoin hahmotettuna opiskelijan motivaatio opinnäytetyön tekemiseen on ikään kuin muuttumaton tekijä, joka on sidoksissa opiskelijan sisäiseen maailmaan ja elämäntilanteeseen. Motivaatiota voidaan tarkastella kuitenkin toisenkinlaisesta näkökulmasta. Ensinnäkin on mahdollista ajatella, että opetus ja ohjaus vaikuttavat opiskelijan motivaatioon. Se on siis muuttuva suure, vieläpä sellainen, johon ohjaaja voi ja pitääkin aktiivisesti vaikuttaa. Tämän jälkeen voi kysyä, mitkä tekijät vaikuttavat opiskelijan motivaatioon ja kuinka hänen kokonaismotivaationsa muodostuu.

Esimerkiksi tietoa tutkimusmenetelmistä on saatavissa runsaasti. Kuitenkaan pelkkä tieto ei riitä. Kuinka motivoida opiskelija käyttämään tutkimusmentelmiä, näkemään niiden mielekkyys ja käyttökelpoisuus? Kuinka saada aikaan positiivisia kokemuksia tutkimusmenetelmien käytöstä ja kuinka nuo kokemukset saadaan siirtymään osaksi ammatillisia käytäntöjä?

Artikkelin aineiston olen kerännyt opiskelijoilta, joiden opinnäytetyön olen itse ohjannut. Aineistonkeruussa olen soveltanut eräänlaista lumipallomenetelmää. Haastattelin ensin yhtä opiskelijaa. Tämän haastattelun teemat jäsensin etukäteen Anne-Birgit Yeungin $(2004,32)$ motivaatio- kartan avulla. Haastattelutilanteessa kävimme kartan läpi ja opiskelija jäsensi omaa opinnäytetyön tekemistään kartan käsitteiden avulla.

Täydensin Anne-Birgit Yeungin motivaatiokarttaa ensimmäisen haastattelun kommenteilla. Lähetin tiedoston viidelle entiselle opiskelijalleni, jotka täydensivät ja kommentoivat eteenpäin tätä tiedostoa. Tämä tapahtui vuorotellen. Lähetin tiedoston ensin yhdelle opiskelijalle, joka palautti sen täydennettynä minulle. Lähetin sen vuorostaan seuraavalle joka palautti tiedoston jälleen minulle.

Valmiin aineiston muodostaa siis "lumipallo", jonka ytimessä on Anne-Birgit Yeungin motivaatiokartta. Keräämäni aineisto on luonteeltaan tämän alkuperäisen motivaatiokartan kommentointia, pohdintaa ja soveltamista kunkin opiskelijan omaan prosessiin ja kokemukseen.

Tulokset tämänkaltaisesta tutkimusasetelmasta ja aineistonkeruusta ovat luonteeltaan kuvaavia. Ne kuvaavat opinnäytetöiden tekijöiden motivaatiota ja siihen vaikuttavia tekijöitä. Aineistonkeruun ja analyysi ovat voimakkaasti teoriasidonnaisia. Aineistonkeruun aikana motivaatiokartta oli kommentoinnin jäsentäjä ja kohde.

Prosessin edetessä opiskelijat vahvistavat alkuperäisen motivaatiokartan sisältöjä ja toisaalta he muokkaavat alkuperäisen motivaatiokartan käsitteitä ja antavat niille uusia merkityksiä. Alkuperäinen motivaatiokartta siis muuttuu prosessin kuluessa. Kun Anne-Birgit Yeungin motivaatiokartta kuvasi vapaaehtoistyöntekijöiden motivaatiota, kuvaa muokattu motivaatiokartta opinnäytetyöntekijöiden motivaatiota.

Syntyvä motivaatiokartta on muotoutunut suhteellisen rajoittuneen aineiston perusteella. Aineisto on kerätty yhdestä oppilaitoksesta yhden opinnäytetyön ohjaajan opiskelijoilta. Kaikki opiskelijat edustavat sosiaalialaa.

\section{Pohdinta - toiminta}

Pohdinta-toiminta-ulottuvuus jäsentyy aineistossa selkeästi. Oman kirjoittamisen, aiheeseen liittyvän kirjallisuuden lukemisen, aineistonkeruun (esimerkiksi haastattelut) ja lopullisen tekstin työstämisen nimeän aineistossa toiminnaksi. Pohdintaan katsotaan kuuluvaksi seminaari- ja ohjaustapaamiset sekä "hidas tekemättömyys ja asian yleinen vireilläolo". Seminaaritapaamisten ja ohjauksen kuvaus sisälsi ilmaisun "jäsentynyt pohdinta".

Tulkitsen, että pohdinnan kategoria sisältää kak- 
si alakategoriaa. Ensimmäistä näistä voi kuvata siten, että opinnäytetyön prosessi on joillekin opiskelijoille jatkuvasti vireilläolova, jopa ahdistava ja yksilön koko olemista jäsentävä kokemus. Se ilmenee "omantunnon äänenä" yksilön muun tekemisen ja olemisen taustalla. Tietoisuus siitä, että opinnäytetyölle pitäisi tehdä jotain - ja mahdollinen epätietoisuus siitä mitä pitäisi tehdä - sekoittuvat jatkuvasti meneillään olevaksi pohdinnaksi.

Ilmaisu "jäsentynyt pohdinta" kuvaa seminaaritapaamisia ja ohjaustilanteita. Seminaaritapaamisissa läsnä on useita ohjattavia, joiden papereita käsitellään vuorotellen. Tämä antaa mahdollisuuden paitsi oman työn ja prosessin pohdintaan, myös yleisempaan opinnäytetyöhön liittyvien asioiden käsittelyyn. Tällaista pohdintaa voi kuvata jäsentyneenä pohdintana - muiden tekemisten tarkkailuna, muiden ideoista ja virheistä oppimisena. Samassa tilanteessa olevien opiskelijatovereiden tekemisten ja ratkaisujen arviointi antaa mahdollisuuden reflektoida ja pohtia omaa prosessia.

Missä määrin opinnäytetyön tekeminen on näin määriteltyä pohdintaa ja mikä tässä kaikessa on niin sanotun toiminnan osuus? Pohdinnan ja toiminnan kategorioiden määrällinen suhde oli erään ilmaisun mukaan jopa 95 vs. 5 prosenttia. Jäsentynyttä pohdintaa ja "asian yleistä vireilläoloa" oli 95 prosenttia prosessista. Kirjoittamisen, kirjallisuuden lukemisen ja aineistonkeruun osuus prosessista oli vain viisi prosenttia. Mielipiteet tästä suhdeluvusta vaihtelivat. Aineiston keruun ja analyysin osuus nähtiin monessa kommentissa huomattavasti suuremmaksi kuin tuo kovin vaatimattoman oloinen viisi prosenttia.

Tulkitsen edellämainitun "95 vs. 5 " asetelman tilanteeksi, jossa opinnäytetyön tekeminen kasvaa tekijänsä mielessä hyvinkin suureksi ja koko olemista jäsentäväksi projektiksi. Opinnäytetyö ja sen tekeminen voivat olla läsnä päivittäin ja liittyä tekijän oman ammattillisen identiteetin jäsentymiseen ja kehittymiseen.

Kokemus opinnäytetyöstä jatkuvasti vireilläolevana ja yksilön koko olemista ja olemusta jäsentävänä prosessina muuttuu negatiiviseksi, mikäli asia ei etene. Tämä asettaa vaatimuksia ohjaukselle.

Ohjauksen puutteen kokemus on aina vakava ongelma. Aineistossa kuvataan ohjauksen merkitystä seuraavasti: "Ohjaus jollain tasolla kertoo opiskelijan arvostuksesta, joku on aidosti tai ainakin työnsä puolesta kiinnostunut siitä mitä teet." Jos ohjausta sitten ei saa, kertoo tämä siitä, että opiskelijaa ei arvosteta. "Miksi tekisin jotain mistä edes koulu ei ole kiinnostunut?"

Opinnäytetyön tekemiselle löytyy tietenkin muitakin syitä kuin ohjaus tai koulun osoittama yleinen kiinnostus. Silti on merkittävää, että ohjaajan tietoisuus opinnäytetyön tekijän prosessista nousee aineistosta niin selvästi esiin. Toimintaan kaivataan "raameja" ja tekijän itsensä ulkopuolelta tulevaa jäsennystä. Tämä koskee paitsi kokonaisprosessia, myös itse seminaaritilanteita. "Seminaarit toivat [..] tiettyä arvokkuutta ja kurinalaisuutta työskentelyyn omine rituaaleineen."

Rituaaleilla viitataan tässä normaaleihin seminaarikäytäntöihin. Sovitun käytännön mukaan käsiteltävät työt toimitetaan sähköiselle oppimisalustalle sovittuun aikaan ennen seminaaria, tilaisuus aloitetaan ja lopetetaan puheenjohtajan toimesta, työt käsitellään aina saman kaavan mukaan (työn esittely, opponointi, yleiskeskustelu, ohjaajan kommentit).

Ohjaajan työn yksi keskeinen ulottuvuus on järjestää seminaaritilanne rituaaleineen. Seminaarin osallistujat saavat ja joutuvat ottamaan vastuuta kommentoinnista. Kun seminaarityöskentely jatkuu lukukaudesta toiseen ja samat opiskelijat osallistuvat työskentelyyn ensin kuuntelijoina, sitten omien ideoidensa ja lähtökohtiensa esittelijöinä ja tämän jälkeen varsinaisen prosessin eteenpäin viejinä, kasvavat yksilöt vastuuseen. Muutamankin keskustelun kuuleminen seminaarissa valmistaa siihen, että itse ja oma työ on jossain vaiheessa samalla tavalla käsiteltävänä.

Osa kaipaa suhteellisen yksityiskohtaista ohjausta. Toisen mukaan kannustavaa voi olla se, että ohjaaja jäsentää prosessia muutaman kuukauden eteenpäin ja antaa selvän mielipiteen, mitä tuolloin voisi olla valmiina. Työskentely itsessään voi sitten olla hyvinkin itsenäistä. Johtopäätöksenä voi esittää, että vastuista ja työtavoista sopiminen prosessin alkupuolella on hyvä käytäntö. Tällöin opinnäytetyöntekijät voivat itse osallistua keskusteluun siitä, millaista ohjausta he arvelevat tarvitsevansa. Samalla tulee sanoitetuksi se, millainen on opinnäytetyöntekijän oma vastuu.

\section{Antaminen - saaminen, etäisyys - läheisyys}

Anne-Birgit Yeungin motivaatiokartassa antaminen - saaminen ja etäisyys - läheisyys olivat kaksi selvästi erillistä ulottuvuutta. Tässä aineistos- 
sa ne kuitenkin jäsentyvät samojen käsitteiden avulla eikä niitä siksi eritellä omiksi ulottuvuuksikseen.

Antaminen opinnäytetyöprosessissa jäsentyi tietoisuuden ja luottamuksen käsitteiden kautta. Antaminen on aineiston mukaan oman prosessin jakamista muiden kanssa. Samalla se on myös omaa tietoisuutta muiden prosessista. Tällainen tietoisuus - eli antaminen ja saaminen - mahdollistuu nimenomaan ryhmässä ja seminaariohjauksessa. Ilman ryhmää tietoisuus prosessista jaetaan vain ohjaajan ja opinnäytetyön tekijän välillä.

"[Opinnäytetyön tekijä] saa tietoisuuden, että joku muu seuraa ja on tietoinen omasta prosessista.” Tällä lainauksella voi tiivistää sen, mitä opinnäytetyön ohjaukselta aineiston mukaan odotetaan. Oli ohjaus sitten ohjaajan ja opinnäytetyön tekijän välistä yksilöohjausta tai ryhmässä tapahtuvaa, on sen tärkein anti nimenomaan ohjausprosessissa syntyvä tietoisuus siitä, että joku muu (ohjaaja, vertaisryhmä) seuraa ja on tietoinen kokijan omasta prosessista. Tämän tietoisuuden merkitys on huomattavasti suurempi kuin minkään tiedollisen ohjauksen merkitys. Ohjaajalta ei edellytetty tai odotettu tietoa opinnäytetyön aihealueesta. Ei nähty tarpeellisena, että opinnäytetyön ohjaaja olisi esimerkiksi vanhustyöstä tehtävän opinnäytetyön suhteen nimenomaan vanhustyön teorian ja käytäntöjen asiantuntija.

Tietoa ja näkemystä odotettiin koskien kahta laajempaa aihealuetta. Nämä olivat tutkimusmenetelmät ja niiden soveltaminen kuhunkin käsillä olevaan opinnäytetyöhön sekä yleisempi ymmärrys ja kokemus tutkimus ja /tai kehittämisprosessista. Vasta kaukana näiden jälkeen tuli esiin tarve saada ohjausta opinnäytetyön sisällöllisistä kysymyksistä.

Ohjaajan välittämä tieto tutkimusmenetelmistä tarkoittaa esimerkiksi tietoa siitä, millaisilla aineistoilla mihinkin tutkimuskysymykseen on mahdollista saada vastaus. Se tarkoittaa tietoa siitä, kuinka pitkään kyselylomakkeen laatiminen kestää ja mitä käytännön toimenpiteitä se vaatii. Edelleen tieto tutkimusmenetelmistä ja prosessista tarkoittaa kykyä välittää tietoa siitä, millaisiin kysymyksiin ja/tai ongelmiin prosessin alkuvaiheessa tehdyt ratkaisut prosessin loppuvaiheissa johtavat.

Ohjaajan on siis kyettävä soveltamaan tietoa tutkimusmenetelmistä kuhunkin käsillä olevaan tutkimus- tai kehittämishankkeeseen. Yleinen teoreettinen ymmärrys ei vie prosessia eteenpäin. Tutkimusmenetelmien hallitseminen tai tutkijan ammattitaito ilman kykyä soveltaa tietoa kyseessä olevaan tilanteeseen ja prosessiin ei auta opiskelijaa eteenpäin. Ohjaamisen näkökulmasta opinnäytetyö onkin ensisijaisesti prosessi.

Aineiston mukaan antaminen on myös opinnäytetyön tekijän oman vastuun ottamista. Tämä tarkoittaa esimerkiksi seminaaritapaamisiin valmistautumista. Prosessiin sisältyy oman paperin valmisteleminen ja valmistellun paperin välittäminen muille osallistujille sovittuna aikana, muiden papereihin tutustuminen ennen seminaaritilannetta ja papereiden aktiivinen kommentoiminen seminaarissa.

Luottamus on edellytys tälle kaikelle. Oman prosessin esitteleminen muille on luottamuksen osoitus. Esittelemällä esimerkiksi tutkimussuunnitelman muille altistaa tekijä oman prosessinsa ja oman tekemisensä alttiiksi kritiikille. Vaikka kritiikki ja avoin vuorovaikutus ovatkin opinnäyte työskentelyn perusulottuvuuksia, ei asia ole itsestäänselvyys. Tarvitaan luottamusta, jotta omia ajatuksia ja tavoitteita uskaltaa esitellä. Seminaarin tai ohjaussuhteen huono ilmapiiri voi estää omien ajatusten esilletuomisen ja sitä kautta prosessin etenemisen. Pelko ja epävarmuus ovat hyvin inhimillisiä kokemuksia eivätkä häviä iän tai ammatillisen kokemuksen myötä: oman alansa rautainen ammattilainen voi kokea syvää epävarmuutta esitellessään omaa tutkimussuunnitelmaansa ja asettaessaan sen muiden arvioinnin kohteeksi.

Ohjaajan näkökulmasta tehtäväkenttä jakaantuu siis kolmeen osaan. Ohjaajan tehtävä on edistää ohjausprosessin mahdollistavan luottamuksen syntymistä. Samoin ohjaajan tehtävä on olla tietoinen ja pystyttävä välittämään muille tietoisuus opinnäytetyön tekijöiden prosessista ja niiden vaiheista. Kolmanneksi opinnäytetyönohjaajan on kyettävä välittämään tietoa tutkimusmenetelmistä sekä tutkimus- ja kehittämisprosessin sisäisistä lainalaisuuksista.

Etäisyyden ja läheisyyden ulottuvuuden kannalta merkittävin asia oli seminaariryhmä. Millä tavalla ryhmä tukee? Seminaaritapaamisissa aikaa ei käytetty juuri lainkaan kuulumisten vaihtoon tai asioihin, jotka eivät suoraan liittyneet opinnäytetyön tekemiseen. Tätä voi kuvata edellä esiin tulleen rituaali-käsitteen kautta. Seminaaritapaamisen virallinen osuus - rituaali - sulkee ulkopuolelle yksityiselämän. Kun puheenjohtaja avaa seminaarin, kaikki toiminta keskittyy opinnäytetöihin.

Tämä ei sulje pois muuta kanssakäymistä. Kuulumisten vaihtoa opiskelijoiden kesken sekä oh- 
jaajan ja opiskelijoiden välillä tapahtui. Sen paikka oli kuitenkin seminaaritapaamista ennen tai sen jälkeen. Seminaarin rituaali rajaa muun elämän pois ja varaa ajan ja tilan.

Aineiston mukaan sen kummempaa tietoista läheisyyden hakemista ei kaivattukaan. ”Jos ryhmässä on hyvä, rento, huumorintajuinen ja luottamuksellinen tunnelma niin se riittää."

Tulkintani mukaan tapaamisten asiapitoisuus synnyttää tietyn läheisyyden. Sitä voisi verrata ammatilliseen läheisyyteen - työkaverit tunnetaan usein vain työhön liittyvissä asioissa. Hyvä ja läheinen työtoveruus ei välttämättä vaadi muuta yhteydenpitoa. Työkavereiden ei tarvitse olla perhetuttuja kyetäkseen tekemään hyvin työtä yhdessä. Näin ohjaussủhde määrittyy eräänlaiseksi työtoveruudeksi. Siinä on yhteinen tavoite eli opinnäytetyön valmistuminen. Ohjaajalla ja ohjattavalla on molemmilla omat roolinsa. Ohjaussuhde toimii sitä paremmin, mitä selkeämmät nämä roolit ovat. Seminaari- tai muu ohjaustilanne on ikään kuin palaveri, jossa käsitellään yhteisen hankkeen etenemistä ja päätetään tulevista toimenpiteistä. Samalla - aina jollakin tasolla - arvioidaan sitä, mitä on jo tapahtunut.

Opettajan rooli ei kuitenkaan saa olla ensisijaisesti arvioiva. Se tuhoaa tasa-arvoisuuden ja vastavuoroisuuden mahdollisuuden. Kuinka sitten olla tasa-arvoinen, mutta antaa negatiivistakin palautetta? Tähän kysymykseen ei ole helppoa vastausta.

Asiaa voisi kuitenkin jäsentää ohjaajan roolin kahtiajaolla. Ohjaajan työllä on kaksi puolta. Toinen niistä on tutkintovaatimusten ja tieteellisen perinteen tulkinta opinnäytetyön tekijöille. Tässä roolissa ohjaaja on vaatimusten asettaja ja arvioija. Ohjaajan toinen rooli on kuitenkin auttajan rooli. Ohjaajan työssä kysymys on siitä, että ohjaaja auttaa opinnäytetyön tekijää tekemään sellaisen työn, kuin hän itse haluaa. Samalla ohjattavan omia tavoitteita pitäisi pystyä kannustavasti suhteuttamaan tutkintovaatimuksiin ja tieteelliseen traditioon.

Läheisyyden teemaan liittyy kysymys ohjaussuhteen vastavuoroisuudesta. Aineiston perusteella on selvää, mitä ohjattavat odottavat saavansa ohjaajalta. Odotus sisältää ymmärryksen prosessista sekä tiedon tutkimusmentelmistä ja niiden soveltamisesta. Saako ohjaaja mitään? Onko suhde kaksisuuntainen? "Valtavan tärkeä on mielestäni tässäkin yhteydessä kokemus siitä, että opiskelijana voisi antaa jotain ohjaajalle - vaikka nyt edes sen valmiin opinnäytetyön kaikkien kamalien vaiheidensa jälkeen".

Aidon vastavuoroisuuden määrittäminen yleisellä tasolla on jokseenkin mahdotonta. Keskeinen sana edellisessä lainauksessa onkin kokemuksen käsite. Tulkitsen, että opiskelijan motivaatiota lisää kokemus siitä, että hän voi tehdä jotain ohjaajan mielestä merkittävää. Tällä tavalla merkittävää voi siis olla esimerkiksi valmis opinnäytetyö tai jokin siihen liittyvä osa tai yksityiskohta.

Vastavuoroisuuden tarve on ymmärrettävissä paitsi yleisinhimillisenä tunnistettavuuden ja hyväksymisen tarpeena, myös ammatillisena vuorovaikutussuhteena. Jos ohjaajan ja ohjattavan suhteen tavoitteena on eräänlainen ammatillinen tasaarvoisuus, ei ohjaussuhde voi olla yksisuuntainen. Ohjattava ei voi kokea tasa-arvoisuutta, jos hän ei koe antavansa jotakin.

\section{Jatkuvuus - uuden löytäminen}

Jatkuvuuden ja varsinkin uuden löytämisen teemat tuntuisivat kuuluvan itsestään selvällä tavalla tutkimus- ja kehittämistyöhön. Onhan tutkimuksen tarkoitus tuottaa uutta tietoa ja kehittämistyössä luodaan uusia käytäntöjä tai tuotteita. Jatkuvuus voisi liittyä vaikkapa siihen, että tutkimusta tai kehittämistyötä ei koskaan tehdä tyhjiössä: se ottaa lähtökohtansa aina olemassaolevasta tutkimuksesta tai käytännöstä, ja myös aina palaa siihen.

Aineistossa jatkuvuus jäsentyi kuitenkin opinnäytetyön tekijän oman prosessin jatkuvuudeksi. On tärkeää, että opinnäytetyön tekijä kokee, että joku muukin on tietoinen hänen prosessistaan. Opinnäytetyöprosessilla on jatkuvuus ja olemassaolo myös tekijänsä ulkopuolella.

Oman prosessin jatkuvuuden eräänlaisena vastapoolina näyttäytyi opiskeluiden ulkopuolinen elämä. Se on opinnäytetyön jatkuvuuden uhka viedessään aikaa ja energiaa. Ritualisoitu seminaari on se maailma, josta opinnäytetyön tekemiseen liittymätön maailma on suljettu ulkopuolelle. Rituaali tarvitaan, jotta voidaan siirtää maailmasta toiseen.

Uuden löytäminen puolestaan jäsentyi uuden tiedon tai käytännön löytämisen riemuksi. Kuitenkin siihen liittyi hyvin voimakas pettymys. Pettymys ei koskenut kokemusta uuden löytämisestä, se määriteltiin positiivisella asteikolla. Sen sijaan pettymys koski uuden, prosessissa tuotetun tie- 


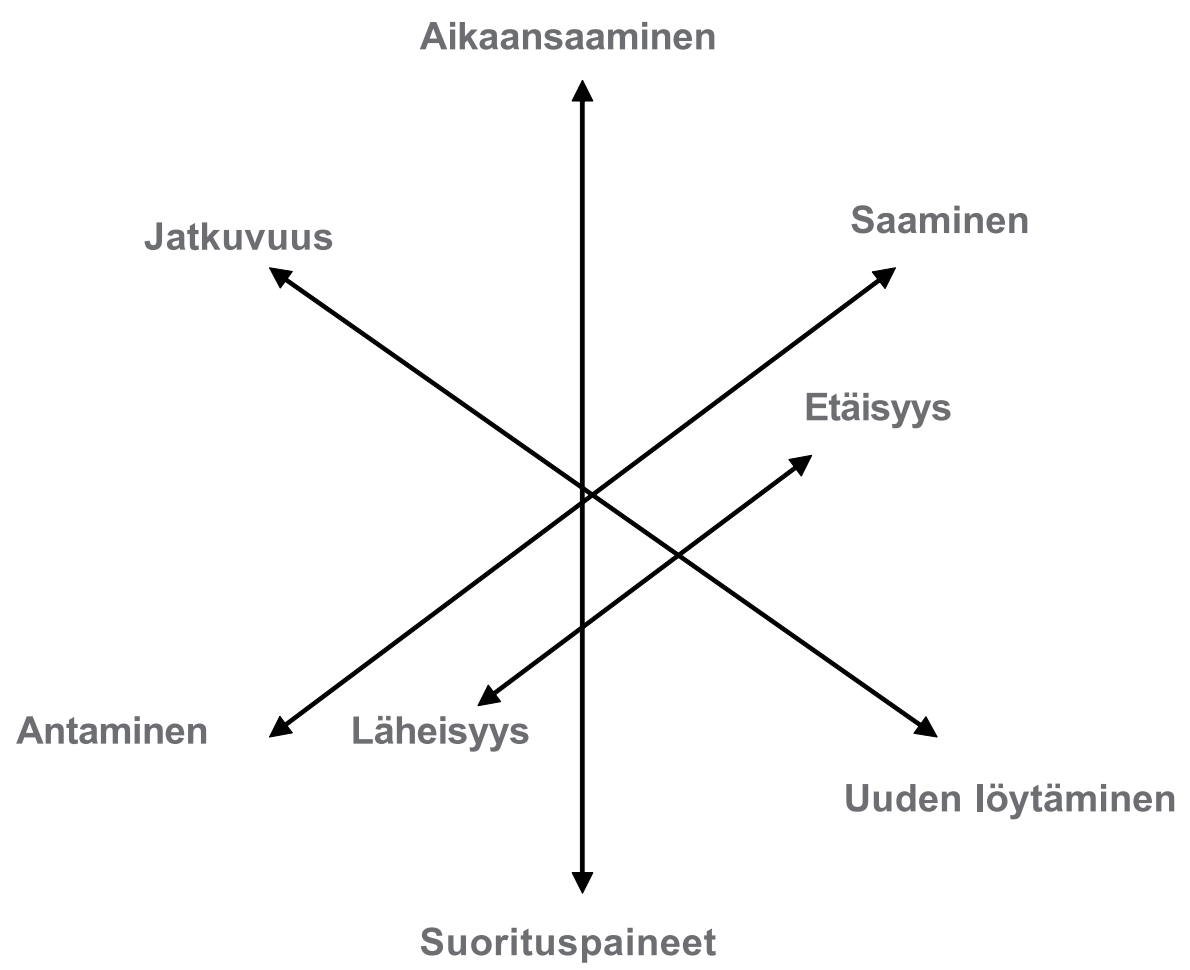

don käyttöönottamista työpaikoilla ja organisaatioissa. Aineistoa kerätäessä oli kulunut jo jopa muutama vuosi siitä, kun opinnäytetyö oli tullut valmiiksi. Kokemus oli, että uusi tieto jäi huonosti hyödyntämättä. Tästä seuraa pettymys.

Uuden löytämiseen liitettiin myös vaaran ulottuvuus. Opinnäytetyön prosessia kuvattiin hyppynä tuntemattomaan. Jatkuvuus tuottaa turvallisuutta ja uusi tieto voi olla siis jatkuvuutta rikkovaa. Tämä oli kuitenkin vain sivujuonne. Uuden tiedon tuottaminen oli positiivinen kokemus. Prosessi imi mukaansa ja innosti työskentelemään.

\section{Yhteenveto}

Yeungin motivaatiokarttaan ei sisältynyt suorittamista ja aikaansaamista motivaation lähteenä. Osalle tämä oli kuitenkin hyvinkin tärkeä asia. Suorittaminen ja aikaansaaminen on osalle opinnäytetyön tekijöistä arvo sinänsä. Asioiden saaminen valmiiksi on motivaatio, jolla pusketaan vaikka läpi harmaan kiven ja tehdään töitä läpi yön. Kaikille asia ei ole näin yksinkertainen. Suorittamismotivaatio voi olla olemassa, mutta sen toteutumista saattaa estää myös perhe-elämän, arkityön ja vaikkapa henkilökohtaisen terveyden kysymykset.
Opiskelijan motivaatio opinnäytetyön tekemiseen on mahdollista esittää seuraavankaltaisen kuvan avulla.

Aineiston perusteella opiskelijan motivaatio on yhteydessä erityisesti jatkuvuuteen ja kokemukseen siitä, että hänen työnsä ja prosessinsa on olemassa ikään kuin hänen itsensä ulkopuolella. Ohjaus ja opinnäytetyö seminaari koettiin ritualisoituneena tilana, joka tarjosi legitiimin paikan varata aikaa oman opinnäytetyötyöskentelyn pohtimiseen ja refelktoimiseen. Prosessi tarvitsee ritualisoidun todellisuuden eli seminaaritilanteen. Muukin strukturoitu ohjaussuhde voi tarjota tilan ja ajan, jossa opiskelijalla on mahdollisuus tarkastella omaa prosessiaan. Siellä tämä ei-vielä-valmis prosessi voi olla olemassa ja tulla koetuksi muutenkin kuin tekijänsä mielessä.

Kuinka ohjaussuhdetta voisi kuvata? Jacquelin Mackinnon (2004) käytti artikkelissaan 'ammattilainen-asiakas'-metaforaa kuvaamaan opinnäytetyön ohjaajan ja ohjattavan ohjaussuhdetta. Metaforan mukaan ohjattava on asiakas, joka saa jotain ammattilaiselta eli ohjaajalta. Hänen mukaansa tämän metaforan käytöllä on yhteys hänen omaan ammatilliseen taustaansa juristina. Juristin ja asiakkaan suhde ja siihen liittyvä etiikka on lähtökohta, josta Mackinnon on itse lähtenyt ohja- 
ussuhdetta. Käytettäessä 'asiakas-ammattilainen'-metaforaa korostuvat luottamuksen, vallan ja tiedon kysymykset. Onnistuneessa ohjaussuhteessa käytetty kieli korostaa yhteisiä velvollisuuksia ja sitoumisia, ei niinkään osapuolien oikeuksia.

Ohjaajan rooli opettajana ei saa olla prosessia määrittävä lähtökohta. Pikemminkin lähtökohtana pitäisi olla tasa-arvoinen mutta roolitettu kumppanuus. Eri roolien (ohjaaja, ohjattava, kommentoija) sisällöt ja vastuut ovat erilaiset mutta tavoite on sama: valmis opinnäytetyö. (vrt. Mackinnon 2004, 400-404).

En omaa asiakastyön taustaa. Omana ammatillisena taustanani on tutkijan, lehtorin ja projektityöntekijän kokemus. Niinpä omaksi avain-metaforakseni muodostuukin 'prosessi'. Opinnäytetyö on mahdollista nähdä hankkeena, jolla on 'ohjausryhmä'. Ohjausryhmän voi katsoa muodostuvan ohjaajan vetämästä seminaariryhmästä. Jokainen seminaarilainen on vuorollaan 'ohjausryhmän jäsen' ja vuorollaan 'projektipäällikkö'. Projektipäällikön projektina on oma opinnäytetyö. Ohjaajan rooli opettajana liudentuu: hän on ohjausryhmän puheenjohtaja ja hyvässä ohjausryhmässä on muitakin jäseniä kuin puheenjohtaja. Ohjausryhmän arvo on siinä, että siellä "linjattiin, miten edetään, tehtiin päätös, jonka mukaan sitten päästiin eteenpäin”. Näin aineistossa kuvattiin seminaari työskentelyä.

Edellinen lainaus kuvasi opinnäytetyön ohjaamista ja erityisesti sen erityisyyttä kaikkeen muuhun opinnäytetyöhön liittyvään kommentointiin. Opiskelijatoverit, tuttuvat, puolisot, sukulaiset, työkaverit sekä esimiehet ovat kaikki potentiaalisia opinnäytetyön prosessin kommentoijia. Kaikesta tästä voi olla myös vaihtelevaa hyötyä opinnäytetyön tekijälle. Jossain pitää olla kuitenkin virallinen ohjaus, joka määrittää toiminnan linjat ja seuraa asioiden toteutumista.

Tällöin ei kyse ole sisällöllisestä opettamisesta. Ohjattava ei niinkään kaipaa tietoa opinnäytetyön aihealueen sisällöstä tai uusista tutkimustuloksista. Hän kaipaa tietoa siitä, mitä seuraavaksi pitäisi tehdä, mikaä askel prosessissa kohti valmista opinnäytetyötä on merkittävä. Millaisia ovia prosessissa käsillä olevilla valinnoilla avataan ja millaisia ovia suljetaan? Jos tavoitteena on X, mitä on tehtävä jotta sen voi saavuttaa? Entä jos valitsen Y, mitä siitä seuraa prosessin kuluessa?

Opinnäytetyön tekeminen ja erityisesti siihen liittyvä ohjaussuhde määrittyy tässä analyysissä yhteiseksi ammatilliseksi projektiksi. Oppiminen - opiskelemisen tavoite - on hyvin sujuneen prosessin tuote. Prosessi on ohjauksen pääasiallinen sisältö.

\section{Lähteet}

Andresen L. (1999). Supervision revisited: thoughts on scholarship, pedagogy and postgraduate research, teoksessa: G. Wisker \& N. Sutcliffe (toim.) Good Practice in Postgraduate Supervision, SEDA paper 106 (Birmingham Staff and Educational Development Association).

Hakala J. (1995). Tutkielmaopintojen ohjaaja tarvitsee muutakin kuin tukevan oppituolin. Teoksessa J Aaltola \& M. Suortamo (toim.) Yliopisto-opetus Korkeakoulupedagogiikan haasteita. Helsinki: WSOY, 136-162.

Hakkarainen K., Lonka K. ja Lipponen L. (2004). Tutkiva oppiminen - järki, tunteet ja kulttuuri oppimisen sytyttäjinä. Helsinki: WSOY.

Easterby-Smith M., Thorpe R. \& Lowe A. (2002). Management research: An introduction. Lontoo, Sage.

Mackinnon J. (2004). Academic Supervision: seeking metaphors and models for quality. Journal of Further and Higher Education, 28(4), November 2004, 395-405.

Sambrook S., Stewart J., Roberts C. (2008). Doctoral supervision... a view from above, below and the middle! Journal of Further and Higher Education, 32(1), February 2008, 7184.

Styles I. \& RadloffA. (2001). The Synergistic Thesis. student and supervisor perspectives. Journal of Further and Higher Education, 25(1), 97-106.

Yeung A. (2004). The Octagon Model of Volunteer Motivation. Teoksessa Individually together: volunteering in late modernity: social work in the Finnish church. Helsinki: Finnish Federation for Social Welfare and Health.

Zhao Chun M, Golde Chris M., McCormick A. (2007): More than a signature: how advisor choice and advisor behaviour affect doctoral student satisfaction. Journal of Further and Higher Education, 31(3), August 2007, 263 281. 